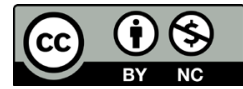

Licenciado sob uma licença Creative Commons

ISSN 2175-6058

DOI: http://dx.doi.org/10.18759/rdgf.v20i3.1784

\title{
(WORDS AND) IMAGES OF POWER IN PIER PAOLO PASOLINI'S PETROLIO
}

\author{
(PALAVRAS E) IMAGENS DE PODER NO PETRÓLIO DE PIER \\ PAOLO PASOLINI
}

Alberto Vespaziani

\section{ABSTRACT}

This contribution focuses on an unfinished novel, Petrólio by Pier Paolo Pasolini to reflect on nature and images of power, as interpreted by one of the greatest Italian post-war intellectuals. The central thesis is that while the peasant and fascist society was based on the male command, on the normative force of tradition, the contemporary consumer society is based on female persuasion, on the push to conform and not to differentiate. However, while patriarchal authoritarianism allowed emancipatory rebellion, consumerist homologation was able to prevent forms of resistance by disseminating power in an infinite network of relationships, whose plot cannot be dissolved. The reading of Petrólio invites the jurist not to focus exclusively on the rational aspects of the rules and procedures that limit power, but also to devote herself to reflecting on the two dimensions of power, the discursive and the aesthetic.

Keywords: Pasolini. Power. Petrólio. Society. Literature.

\section{RESUMO}

Esta contribuição se concentra em um romance inacabado, Petrólio, de Pier Paolo Pasolini, para refletir sobre a natureza e as imagens do poder, interpretadas por um dos maiores intelectuais italianos do pós-guerra. A 
tese central é que, enquanto a sociedade camponesa e fascista se baseava no comando masculino, na força normativa da tradição, a sociedade de consumo contemporânea se baseia na persuasão feminina, no impulso de se conformar e não se diferenciar. No entanto, enquanto o autoritarismo patriarcal permitiu a rebelião emancipatória, a homologação consumista foi capaz de impedir formas de resistência, disseminando o poder em uma rede infinita de relações, cujo enredo não pode ser dissolvido. A leitura de Petrólio convida o jurista a não se concentrar exclusivamente nos aspectos racionais das regras e procedimentos que limitam o poder, mas também a se dedicar a refletir sobre as duas dimensões do poder, o discursivo e o estético.

Palabras-chaves: Pasolini. Poder. Petrólio. Sociedade. Literatura

Constitutionalism, as a political and legal doctrine, seeks to divide, organize and limit power. In order to prevent power's arbitrary exercise, constitutionalism focuses on institutions, procedures and protections, glorifying the law's empire and its rule. But rather than examining its underlying notion of power, constitutionalism just takes it for granted. The related disciplines of political science and international relations (at least in their realist varieties) do try to measure power; constitutionalism, by contrast, takes its concept of power for granted, while attempting instead to measure law. But in focusing too exclusively on formal data, norms and procedures, constitutionalism cuts itself off from a serious reflection on power.

One of the tasks of the law and literature approach is to redeem legal thought, in this case constitutional thought, from its tendency to self-referentiality. Literary reflection is a fruitful method for better understanding constitutional law. It enables us to look beyond constitutional doctrine or jurisprudence, in order to confront the practices and narratives that structure the power that constitutionalism seeks to harness. A reading of Petrolio invites the jurist to overcome a tendency to concentrate exclusively on the rational aspects of the rules and procedures limiting power, to focus instead on the two dimensions of power, the discursive and the aesthetic.

It is in this spirit of reflective confrontation that this paper examines the nature and images of power in this unfinished novel by Pier Paolo 
Pasolini, one of the greatest postwar Italian intellectuals. Pasolini thought deeply about power, its nature and its transformations in Italian society. He did this in the many fields in which he ventured: poetry, literature, journalism and film. After a cinematic and literary career dedicated to an affirmation of life, Pasolini dedicated what would be the end of his life to mirroring, narrating and representing the dissolute dynamics of power. His final works, the film Salo or the One Hundred and Twenty Days of Sodom, and the novel Petrolio, together constitute a formidable phenomenology of power. Salò was released after Pasolini's death, and stands as an explicit rejection of his earlier "life trilogy" (The Decameron, Canterbury Tales and The Flower of A Thousand and One Nights), in favor of a dark representation of the nature and disciplinary mechanisms of power. Contrary to the popular view of Fascism as imposing a welcome degree of law and order, Duke Blangis in Salò asserts that: "once we have taken over the state, we Fascists are in fact the only true anarchists. The only real anarchy is that of power." In an interview with the newspaper Il Tempo, Pasolini declared that "the message of Salò is a condemnation of the anarchy of power and its denial of history."

Petrolio should have been Pasolini's greatest achievement, the complete work bringing together his mature ideas about the transformations of post-War Italian society. The original project was vast, and Pasolini only completed about a quarter of it. In a 1975 interview with Luisella Re, Pasolini announced that "I have started a book that will take me years, maybe the rest of my life. I don't want to talk about it though. It is enough to know that it is a kind of summa of all of my experiences, of all of my memories." From this ambitious project, we have a total of 522 pages (of which 492 are typewritten). Petrolio is a massive, messy work in progress, an unfinished draft; it takes the form of an assembly of fragments, which Pasolini himself referred to as Notes, some much more elaborate than others.

To his great friend Paolo Volponi, Pasolini confided: "well, now that I have finished Salò, I am done making films, at least for many years. For precisely that reason, I wrote the Abiura della Trilogia della vita (Rejection of the Life Trilogy), and I am done with film. I want to return to writing. In fact, I have begun writing again. I am working on a novel. It will have to 
be a long novel, of at least two thousand pages. It will be called Petrolio. It will cover all of the problems of our Italian political and administrative life, the crisis of our republic, of the last twenty years: it will center on petroleum, the great mover of our supposed neo-capitalism, of the international division of labor, of the financial powers that produce this crisis, our suffering, our immaturity, our weakness and, together with that, the conditions for the subjugation of our bourgeoisie. It will contain all of this, and there will be different characters. But the main character will be an industrial manager in crisis."

To appreciate the context in which Petrolio was written, it is worth remembering that Enrico Mattei had died in 1962, and that Francesco Rosi's film about him, Il caso Mattei, came out ten years later, in 1972. The novel itself is initially set in the Rome of the late 1950s, and Pasolini animates his characters with the distinct jargons of those times, "the way they change the subject (always in strictly economic spirit, except for certain insignificant/digression/ of a southern and forensic character). But for me, a person who is within a certain circle of power (when it's not a question of a dictatorship, because then everything is much simpler) can only be an apparition" (30). The main character is Carlo, a well-educated, bourgeois Turinese in his forties. Carlo is an engineer working for ENI, the Italian state energy corporation and, in Pasolini's description, " $a$ / topos/ of power" (76). Carlo is a liberal Catholic, a "(Catholic of the left in the accepted meaning of the phrase during the Papacy of John XXIII). To anyone observing him, Carlo manifested an essential characteristic: that of being interested in everything and of remaining perfectly / unchangeable/. Just as a subordinate should be unchangeable, should have no feelings. But at the same time this unchangeableness was that of a manager, who, in contrast, must not reveal his feelings, being above them. Carlo, lacking the habit of power, had, it's true, the look of a sacristan, of a provincial just come from a college of priests: and his thickset body, with the grey pants and black jacket that made his soft, heavy, awkward figure stand out even more; his round head, where the black hair was already prematurely falling out in the middle, leaving a clear empty space similar to a monk's tonsure; the face round, too, with the big sad eyes in the middle, almost weeping, but at the same time full 
of tension and an obstinate will, which was also priestlike - everything about him was reassuring as to the high quality of his hypocrisy and an honesty not without a Machiavellian side, that is, the capacity to silence conscience for the purposes of good" (103-4). Pasolini thus presents his main character as someone who, "growing up, automatically became part of the intelligentsia that I have called enlightened; triumphantly he entered the leadership minority of the élite, which has, besides a pragmatic knowledge of power, an ethical one, and which, precisely by means of a critical attitude toward it, /preserves it/, masking its violence. [...] All that made him a bourgeois profoundly tied to the bourgeoisie and in fact destined to power; but it made him, at the same time, a man who would contribute to the bourgeoisie and its power a radical criticism (with the attached knowledge); and, moreover, guaranteed it a kind of opening toward the extreme left, without which a modern power is not even conceivable. This 'perfection' of Carlo's, which was also reflected in his physical appearance (the stunning white hair cut short but not too short, its pure whiteness framing an /athlete's tanned/ healthy face; the vaguely imploring and slightly intoxicated softness of the blue eyes, which the habit of power from time to time hardened to a metallic gray), this 'perfection' of Carlo's - his being a man of power without illusions; that is, without the innocence of the practical man, who has an ancient, infantile idea of power - would save him from even the least impurity of existence: guaranteeing him the absolute irreproachableness of the tolerant man" (338).

Carlo's relationship with power is not without its ambiguity. On the one hand, he desires it, and he is at home in the halls of power. But through the "visions" that Pasolini attributes to him, he comes to hate it too: "I suppose that just as hatred of power is idealistic, so is the desire for power. And perhaps it is superficial to condemn, by choice and without discussion, the desire for power. The form of idealism that gives life to that completely uniform city of the wealthy, or at least of the well-to-do bourgeoisie, with its internal hierarchies, its coteries of snobs, of marginal types who are tolerated, etc., up to those with true power, directors of banks, big business executives, entrenched bureaucrats, government ministers, is a natural and - I must even write this - innocent desire for power./ Those 
who - as in my case - hate power have, at some moment or other in their life, an inaugural moment, loved it, because that is natural and because it's what later provokes a hatred that - besides being almost religious! - is justified. Our hero, through all the metamorphoses - as ambiguous and incomprehensible, and perhaps also as arbitrary as one likes - was a man whose life was defined by a "natural and innocent desire for power" (211).

Carlo is passionate but inalterable. He is a shrewd operator, but with an initially straight ethical compass; he is a man of his times and, as such, is perfectly integrated into the Italian culture of his times, which "was very uniform, in the accepted historical-ethnological sense of culture [...], in its particular bourgeois and academic sense, and finally in the sense of being an /élite/ culture, embodying the hierarchy of values that placed it at the top in the country. The cultural hegemony of the left still dominated, just as it /had coming out of/ the Resistance, and while sociology and the technological myth were beginning to advance, it was a 'renewal' that, on the one hand, put the old Marxist intellectual in crisis and the other revitalized him. But anti-Fascism and progressivism were still the unifying force in an Italy made up almost entirely of peasants. The young men plotted their happy reinventions in the shadow of their fathers (who, as I have said, watched them benevolently, in a traditional relationship). It worked well. Italy had never cultural activity more fervid, intense, and virtuous than in that period. There was still room for scandal, because power was /tightly held/ by the Christian Democrats, whose obtuse brutality made the cause of anyone who opposed them so much more noble. In conclusion, the roles assigned to all were distinct: a worker was clearly distinguishable, by his physical presence alone, from a bourgeois; and similarly an apprentice mechanic from a student; an intellectual of the left from an intellectual of the right; an academic from a writer. Confusion was not possible. Never, for example, would an overambitious literary person belonging to the subculture (in the hierarchical sense) be confused with a literary person of value, that is, one who belonged to the culture. His very physical presence would betray him" (105).

Here Pasolini illustrates his well-known argument about anthropological mutation: before the neo-capitalist transformation had created a leveled society of indistinguishable consumers, social roles and 
even individual bodies had been clearly distinct. Society had its hierarchy, sons could rebel against their fathers, who knew in turn what to expect. It was possible to distinguish real values from their opposites. In Pasolini's prophecy (which we can now appreciate as sharp historical description), social leveling produces a homogenization of discourses and social roles, leading to a nihilistic inversion of values and the triumph of mediocrity and middle-class resentment. The Italian society that we see in Petrolio stands at the edge of a great transformation, just as Carlo is about to be upended by transformations in his sexual identity. While Italian society transforms from agrarian and patriarchal to industrial and consumerbased, Carlo transforms into a woman, and from a power-hungry man into an enemy of power. Pasolini describes Carlo's sexual transformation through a series of visions, rather than stories or speeches.

In a note to the second part, Pasolini writes that "The love of Carlo the Meek for the Communist young men of the people - which transforms him into a woman, makes him their slave - turns into hatred in the Carlo with Power, who in his anti-Communist role participates (unconsciously, however, in a psychoanalytically anomalous way) in the slaughter. After the slaughter he feels the remorse of the whole Italian bourgeoisie for being bloodily anti-Communist (a nightmare of blood). That remorse lays down the prerequisites for an analogous anti-Fascist action (which restores a democratic conscience - naturally false)" (149).

The theme of identity thus runs through Pasolini's examination of the parallel transformations of both Italian society and Carlo's gender. These transformations are not necessarily represented as degenerations of identity. On the contrary, they make-up the very essence of a kind of Dionysian vitality. The Apollonian forces dedicated instead to the preservation of identity are, by contrast, reactionary, obsessively bent on discipline and social control: "this poem is a poem of obsession with identity and, at the same time, its destruction. Dissociation is order. The obsession with identity and its destruction is disorder. Therefore, the theme of dissociation is merely the narrative rule that ensures the limitedness and legibility of this poem; which, on account of the other, truer theme, the obsession with identity and its destruction, would by its nature be limitless and illegible" (150). 
Carlo's sexual identity therefore transforms together with the dominant values of society: while peasant society was dominated by the commanding father figure, neo-capitalist consumer society is marked by the feminization of relations, with a new importance given to advice and strategies of persuasion, less violent but more effectively imposed. Note 63 is impressive for its analysis of the reactionary character of this neo-capitalist society, as well as for its prescience in foreseeing the violent season of terrorism about to hit Italy: "The death of Feltrinelli, along with the revolts of the extraparliamentary groups, which were now isolated from the rest of the nation - a nation blackmailed by the events of '68 and therefore inclined to remember with loathing - had given a further impetus to Fascism, which, in spite of everything, in spite of the desperate efforts of the few honest /and ingenuous/ political forces, had already been tremendously strengthened by the slaughter in Milan and the two hundred other bombs, which had not resulted in any casualties but / were part/ of the same program. The Fascists in all positions of power began their /counteroffensive/, their series of tactical exchanges, /etc./; the Church was finished, the Curia remained, that was enough for a return to a clericalism that could conceive of the Fascists as possible allies: the basis of their possible understanding - which began pragmatically with exchanges of men in the centers of 'power' - was simply 'power', in and of itself, stripped of every sort of attribute; since a clericalism that desires the power of the Church is inconceivable without the Church; and a Fascism without tradition that wants traditional power is inconceivable. The people were those Carlo had seen - in a terrible flash - on that day in March 1972 as he rushed by car from Milan to Rome on the Aurelia; those were the people; and they no longer had the old values of the Church or the corrupt values of conservatism: stupid, brutal, sneering, empty, neurotic, anxious, casual, undifferentiated; the young men all wanted the same thing, and it was nothing but the eternal repetition of a model, which made all the contents the same; a civilization was beginning whose center was not a particular man but groups of men; the man-hero, still /however/modest, like Carlo, was something now inconceivable except to men of a certain age, who still felt respect - respect even for those who did not deserve it - which was therefore in itself something noble, ennobling life" (204). 
As Emanuele Trevi sharply observes, "In his creation of a kind of erudite, purely suggestive, atmosphere, Pasolini is not at all interested in citing Carlo's initiation rites into the Eleusian mysteries. When he writes Petrolio or films Salò, he has gone into the beyond, not in the way of a mere explorer, but rather of someone who will never go home. Petrolio is the live recording of an initiation, or rather of a taking possession of reality. First Carlo's division, and then his sexual metamorphosis [...] are the conditions through which a new vision can emerge" (Trevi, 2012, 183).

Petrolio's swarming structure alternates between descriptions of Carlo, his relationship to the power that he has and desires, and delirious Satyricon-like visions of the iconography of power. In Note 65 bis, the Medieval Garden, Pasolini gives us this theatrical vision of power: "to the right, /on the other hand/, were Divinities of a completely different type and nature. They were the First Father, the State, Order, Folly: these divinities did not appear to be at all obliging; on the contrary, they seemed to demand silence and prayer. It was impossible to predict whether or not they would yield. Something - equally impossible to predict - was needed to distract them from the task they were engaged in. The First Father was holding one of Folly's breasts tight in his hand, like an apple, and that had caused him to have an erection; he looked into space with burning eyes, his hair blowing in the wind. Not Romanesque but Art Nouveau, to the expert eyes of Carlo and the author. Order was intently reading a book from the early twentieth century. The State was pompously consulting some Greek texts: but not classical Greek. Folly, with the nails of her monstrous foot, was absorbed in scratching the head of a Divinity so low in stature that at first it could not be seen: the head was very large with a jutting forehead above a snub nose. It was Power" (215).

In Note 67, The fascination of Fascism, we encounter instead a speech on the relationship between power and history, and on the desire to obey that power as a spur to the construction of a transgenerational identity: "Thus the mystery of existential experience is a mystery above all of the Past: not only of the Past as it appears to us in the Present (the mystery of fathers) but also of the Past as it appears to us in the Future (the mystery of sons). The continuity of the element of transience is identical to the continuity of the Past and its bodily mystery. That continuity invades all 
life, is its continuous record. The stability of the Present, the Institutions, and the Power that defends them are based on this feeling of the Past, as a mystery to live again; if we did not delude ourselves that we refashion the same existential experiences as our fathers, we would be seized by an unbearable anguish, we would lose the sense of ourselves, the idea of ourselves; and the disorientation would be total. All the more since the mystery of the history of fathers is identical to the mystery of the history of our sons. Fascism expresses all this in a primitive and elementary way; thus it gives first place to an irrational philosophy and to action, which are the actual and logical forms of bodily Mystery. No one of us is exempt from it, undamaged or free. Even when we do not want it, the Past determines the forms of life that we imagine or project for the future. Fascism is the ideology of the powerful, the Communist revolution is the ideology of the powerless. The powerful and the powerless of the moment, of course. In the historical moment in which it is current. The powerful are also torturers, the powerless also victims. There is something absolute in the mind of the man of power who wishes to stabilize the Past; while there is something precarious in the thinking of the victim who wishes to destroy the past. In the man of power there is no ambiguity; similarly in those who decide to obey the powerful and therefore, in return to benefit from power. Victims, on the other hand, are profoundly ambiguous; their decision to reject the power that is within reach in order to create another in an uncertain, improbable, often idealized and utopian tomorrow cannot but arouse suspicion. The man of power can be condemned (for his abuse of power, his violence, his aggression, his vulgarity), and so can young men who, having reached the moment of choice, decide to stay with the powerful, to serve them, with the purpose of sharing in power and, a little at a time, becoming truly powerful themselves; but in all this there is nothing suspicious; it is, I would say, natural. In fact, it is difficult to imagine how it would ever enter anyone's mind to make the opposite choice; that is, to renounce the course of life that, putting him in the service of power, with his youthful self-confidence, assures him by seniority and old age power and prestige; and to choose instead the life of a victim, excluded from the great paternal banquet of power: the glorious repetition of life as the Past that goes on forever" (226). 
It is precisely at this point in Petrolio that Carlo becomes aware of his own sexual metamorphosis. In Note 58, "Second fundamental moment of the poem," a half drunk Carlo sees his own changed body in the mirror. And right after that, Note 59 carefully describes the social metamorphosis of his time: "Italy was headed toward the Hedonism of Consumption - if the reader will allow me this superficial definition - whose temple was certainly not the Church. A hedonistic Fascist was a contradiction in terms. Power was caught in the impasse of this contradiction. [...] Power is eternally young, malleable, often in doubt and in crisis, like every human thing. Now its followers were called into question. The Opposition had reorganized itself and had regained a certain traditional unity based on the rhetorical idea of Power, traditionally understood as 'old, stupid, obtuse, without dilemmas'. Leftism had lost the masses, because a subculture of protest against a subculture of power is an antithesis that can end only in the defeat of the former. The masses of youths had enigmatically returned to normal, despite visibly retaining the traumatic signs of the revolt of some years before. That, however, had turned against them. The total, intransigent condemnation that they had pronounced against all the fathers, without distinction, had kept them from having a dialectic relationship with those fathers by means of which to overtake them, to pass them by. Pure rejection is boring and tiresome. And so, by their rejection, the young found themselves stuck in history. Which meant, fatally, a regression. The physical and psychological characteristics of an old, unhappy bourgeoisie reappeared in them, signs that had disappeared, at least in a small way, in their fathers: the faces of old priests were seen again, of guilty lawyers, of vain judges, of corrupt sergeants, etc., etc.: this in the most defenseless youths, of course. In the 'mass' there was nothing but discontent, neurosis, ignorance, aggression; integration did not pay for the betrayal. The approach of the periphery to the center, of the provinces to the capitals, had meanwhile destroyed the varied, particular popular cultures as well. The outskirts of Rome and the poor lands of the South, the small traditional cities and peasant regions of the North no longer produced their own human models, whose origins lay precisely in the old cultures: human models to oppose to those offered by the center, through the press and television, gently imposed. And since it was a petit bourgeois model, the huge number of pooryouths who sought to 
conform to it were frustrated by it. The pride of the people no longer existed. Rather, the extra thousand lire that prosperity had put in the pockets of proletarian young men had made those young men foolish, arrogant, vain, mean. It is only in poverty that the goodness of man is manifested, even it is illusory. By now there was no young man on the people who did not have stamped on his face a sneer of self-sufficiency, who looked anyone in the eye anymore or did not walk with eyes lowered, like a schoolgirl showing dignity, reserve, and morality. There was no longer any curiosity at all. Everything was compulsory known. There was only a nervous anxiety - which made the young men ugly and pale - to consume their piece of the pie. [...] The only reality that beat with the rhythm and breath of truth was the implacable reality of production, of protecting the currency, of maintaining the old institutions still essential to the new power, which certainly were not the schools or the hospitals or the churches" (227-229).

The new discourses of power, politics, education and television changed Italian society, loosening its traditional anchors with breakneck speed. For Pasolini, the strategy of tension is therefore deeply enigmatic, in that it aims to violently destroy an already-changed life world with the soft instruments of mass persuasion. It is also for this reason that Power fears these Visions, which force it to confront its own vacuity: "power is always, as they say in Italy, Machiavellian; that is realistic. It excludes from its activities everything that can be 'known' through Visions. [...] The stupid behavior of Power (in assembling an enormous machinery, made up of a chain of common crimes, to destroy something that Power itself has already destroyed by other means) is really, at least in this context, enigmatic" $(403,404)$.

Power resists the Visions, it fears their ability to unmask its ideological content. In an earlier work, Teorema, Pasolini had replaced dialogues with mute images. In Petrolio, power is both the force of persuasion as well as an environment, a subtle way of acting in particular social situation, a suave way of speaking and a particular way of lying. In Note 125, "A Fascist demonstration," Carlo "goes to the café where his friends meet (thirteen years older than when he last saw them). He arrives there like a sleepwalker. To the others he is a man of power; he has reached the highest pinnacle of his profession. Qualities of an inhuman order are 
attributed to him. As though he belonged to a theophany. His friends, who have had modest careers in the city (yet which in the sphere of the city have proved to be high-ranking, respectable; in a certain sense more respectable than Carlo's, which is not unconnected to the idea of something adventurous, unstable, bound to the corrupt capital, and of a socially inferior quality), welcome him with respect disguised - without any effort and, in fact, with surprising naturalness - by familiarity and cordiality. Their experience, philosophical, restricted, conditioned by a life without alternatives, has, however, a perfection of its own. In their knowledge and their cultural attitudes they very much resemble one another; but what truly unites them is a shared form of humor, very warm and vital, which Carlo is unused to. Political men who are successful - even if they come from environments like that, $\mathrm{xxx}$, from cafés like the one in Via $\mathrm{xxx}$ - are infinitely poorer, duller, more provincial. A discussion begins among the old friends - one of those discussions that in Rome, particularly in the world that has become Carlo's world, are impossible (except in bad faith). The political big shot can't help but always be a demagogue and a liar; the one who holds true power - who is publicly less well known and has no need to beg continually for popularity, strutting like a peacock, but is cold and totally cynical - relaxes a bit and becomes a boy only in his hobbies. The old Turinese friends, who have spent their entire lives where they were born, can also still enjoy, it seems, besides good food and good wine, a disinterested intellectual discussion (which spawns practical initiatives parallel to power, but in Calvinistic - as far as that may be possible in Italy, and particularly, surely, in Turin - polemic with power). In a discussion of this kind Carlo uses ideas that are worthless in the sphere of power, where, for something to be made concrete, realized, purely formal notions are needed, that is, notions that can be directly translated - and without the oppositions of pure reason - into actions, into deeds. For a political man, to have real conversations is to be an academic" (426-427).

In the following Note, 126, Carlo stumbles upon a Fascist parade and, with great disappointment, realizes that Fascism is over: "The peasant world, the world of the people, is finished. It was from the poorest parts of this that Fascism drew its bands of innocent, manly killers. It's also the end for the middle classes, whose bourgeois culture was still based on popular 
culture (similar to that of the killers): peasant, pastoral, seafaring, poor. Distinct (from region to region, from city to city, from center to periphery). Singular, particular. Therefore real. After the war, the new power (which Carlo was directly a part of) relied on these cultural forms, which were real but electorally reactionary. That is, it did the same thing Fascism had done. But then, slowly, imperceptibly, the nature of that power changed radically. [...] The life style preached by that power (every day, every hour, every moment of life) was completely unreligious. Nothing in the world - throughout all those years - could be considered more unreligious, for example, than television. It's true that television often showed official inaugurations, with a ridiculous bishop present; even more often, it showed religious ceremonies, with the Pope himself, etc. But all that was only an image of the parades of power: the religion of the State. In reality television preached pure hedonism, every day, hour after hour; its thrust was totally in the direction of prosperity and consumption. And the people had learned the lesson in a radical way: palingenetic (for the first time in history). They had mutated. They had made their own new human models, proposed by the culture of those in power. They had abandoned their traditional models. Existentially they had experienced new values, which they were still only nominally conscious of. Life was in advance of consciousness. Indulgence, necessary to the hedonistic ideology of consumption, imposed new duties: those of being equal to the new freedoms that, unnoticed, had been granted from above. Inevitable causes of neurosis. On the other hand to experience new values existentially without knowing them was in turn a good reason for neurosis. The peasant world had crumbled. The countryside (and the seminaries) was full of vipers. That world had lost its own traditional and real values, along with the conventional ones imposed by the official religion. What replaced those values? And what, too, were the values of the petite bourgeoisie? No one - of those in power - had ever told the truth; that is, that the new values were those of excess, a fact that made lives superfluous and thus hopeless" (430-431).

It is astonishing to read Pasolini's prescient description of the anthropological mutation caused by the advent of neo-capitalism and the corresponding triumph of consumerism. For law and literature studies, Petrolio is striking for its rejection of a narrative structure and its search for 
a new form, described as a whirl or as a shish kebab, in which fragments, discourses and visions come together in a delirious representation that pierces the ideological veil to arrive at an understanding of the nature of power. Characterized as a modern Satyricon (which Fellini had brought to the cinema in 1969), Petrolio is also an invitation to dwell upon the aesthetics and iconography of power. The images and visions of power are more revealing than the discourses on power. The rationalizing purpose of narrative coherence is, for Pasolini, a symptom of an identitarian obsession, which generates ideological violence and false conscience. On the other hand, accepting the iconic whirl and the dissociation of the representations of power is the only form of order humanly acceptable. This is because the vision, in contrast to the written word, is not mediated by critical reflection. The act of writing reveals that which is mistaken in the act of thinking. Writing a first draft involves the elaboration of rough thoughts, which are sometimes elaborated in the very act of writing, and are not the mere transcription of fully-formed thoughts. Only in writing, not in reading nor in watching, does self-understanding change the text.

The synchronic transformations of character and society in Petrolio allow us to glimpse the basic argument of this paper: Carlo's sex change corresponds to the anthropological change of Italians. While agrarian, Fascist society was based on "hard" masculine command and the normative force of tradition, consumerist society is based on "soft" feminine persuasion, on the pressure to conform and fit in. Still, while patriarchal authoritarianism left space for a liberating rebellion, consumerist leveling has prevented forms of resistance from arising in the first place, disseminating power in an infinite web of relations, which cannot be fully grasped nor challenged. Power, understood in this way, is hardly amenable to the restraints of constitutionalism, which must itself evolve to safeguard freedom. 


\section{BIBLIOGRAPHY}

PASOLINI, Pier Paolo. Petrolio, translated by Ann Goldstein. Pantheon Books, New York, 1997.

TREVI, Emanuele. Qualcosa di scritto. Milano, 2012.

Recebido em: 9-9-2019

Aprovado em: 17-12-2019

\section{Alberto Vespaziani}

Doutor em PhD pela Università degli Studi di Roma La Sapienza (2001); LL.M. (Harvard, 1998); professor associado de Direito Público Comparado na Universidade de Molise, Itália. Membro da Red Brasileira de Direito e Literatura e do LABIRINT. E-mail: alberto.vespaziani@unimol.it

Università degli Studi del Molise. Molise - Itália

Via Francesco De Sanctis, 1, 86100 Campobasso CB, Itália 